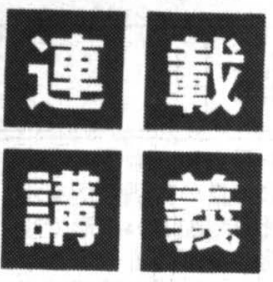

\title{
溶接アークプロセスの物理 $[\mathrm{IIII}]$ \\ 一電極ワイヤの溶融速度と温度分布ー*
}

\author{
平田好則**
}

\section{Physics of Welding [III] \\ - Melting rate and temperature distribution of electrode wire-*}

by Yoshinori Hirata**

キーワード:ミグ・マグ溶接, ワイヤ溶融速度, 抵抗発熱, 熱伝導, 突 き出し長, アークの電極加熱, 溶滴の保有熱量

\section{1. はじめに}

ミグ・マグ溶接などのガスシールドメタルアーク 溶接 (GMAW) に代表される溶極式アーク溶接法て は, 溶接ワイヤや溶接棒がアーク放電の電極となる. 電極のワイヤ・棒はアーク熱によって溶融し, 溶滴 となって溶融池へ移行する. 溶滴がワイヤ端から離 脱する毎に断続的にアーク長が変化する．したがつ て, 移行する溶滴の大きさや形, 移行頻度は溶接ア一 クの安定性を支配し, 作業性や溶接品質に影響する. すなわち, 電極ワイヤ端から移行する溶滴のサイズ が, 大きすぎたり，ふぞろいになったりすると，溶 滴移行にともなうアーク長やアーク発生位置の変動 が大きくなり，アークが不安定になる．また，溶滴 の移行がスムーズでない場合には, 溶接棒端や溶融 池から溶融金属が飛散するスパッ夕現象が生じる.

一方, 電極ワイヤや溶接棒の溶融速度は, 単位時間 当たりの溶着金属量に直結し,溶接能率を支配する.

これらの電極ワイヤの溶融移行現象は, 溶接法や 溶接条件 (電流, 電圧), 極性, シールドガス, ワイ

\footnotetext{
*原稿受付 平成 6 年 8 月 8 日

**正 員 大阪大学工学部 Member, Osaka University, Faculty of Engineering.
}

ヤの材質・種類 (ソリッド, コアード), ワイヤ径, 母材など多くの操作因子によって変化する。本稿て は, 電極ワイヤの加熱・溶融現象を理解する上で基 本となる突き出し部の温度分布とワイヤ溶融速度に ついて述へ，次号においてワイヤ端に形成された溶 融金属の離脱・移行の機構について解説する.なお, 本講義で扱う対象は, ミグ・マグ溶接, 炭酸ガスアー ク溶接など溶接ワイヤを主として定速送給する溶接 法の溶滴移行現象とする.

\section{2. 電極ワイヤの温度分布}

周知の通り, 固体ワイヤ端には溶滴が付着してお り, 溶滴を含む端部領域がアーク熱によって加熱さ れる. 電極ワイヤの温度分布や溶融速度を考える上 で, ワイヤ端の溶滴の形成や離脱の現象は問題を複 雑にする. そこで, いくつかの仮定のもとで成り立 つ簡単なモデルを用いて述べることにする。

\section{1 熱伝導方程式 ${ }^{11}$}

図 1 は電極ワイヤの温度分布を推定するのに用い られる座標系を示す.すなわち, ワイヤ先端 $\left(\mathrm{x}=\mathrm{E}_{\mathrm{x}}\right)$ の温度を融点とし，アーク熱によって融点以上に加 熱された溶融金属は, ワイヤ端部 $\left(\mathrm{x}=\mathrm{E}_{\mathrm{x}}\right)$ から次々 と連続的に離脱, 母材へ移行するものと仮定する. 


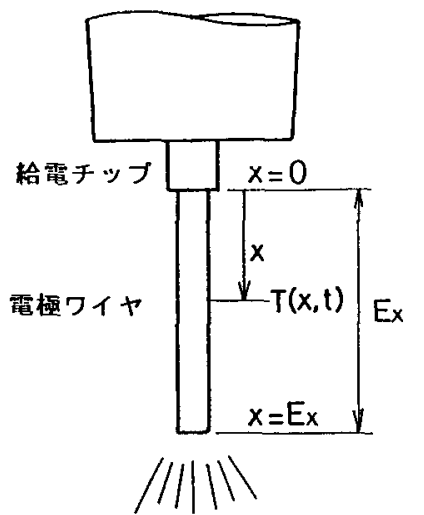

图 1 電極ワイヤの温度分布を計算する座標系

したがってここの計算モデルのワイヤ端には，溶滴 が存在しない。ワイヤ端から流入した熱は，ワイヤ 突き出し部 $\left(x=0 \sim \mathrm{E}_{\mathrm{x}}\right)$ を熱伝導によって移動し, 温度一定の給電チップ（通常，トーチは水冷ないし は空冷されているので, チップ温度もほほ一定と考 えてよい) に流れ込む。あわせて，溶接電流はこの ワイヤ笑き出し部を通って，ワイヤ端からアーク放 電部に流出するので，ワイヤの材質や径，突き出し 長さによっては抵抗発熱による温度上昇の影響を無 視できない。

上記の仮定をもとにワイヤを一定速度で送給する とき, 突き出し部の温度分布は, 次の 1 次元熱伝導 方程式で表現できる。

$$
\frac{\partial T}{\partial t}+v_{w} \frac{\partial T}{\partial x}=k \frac{\partial^{2} T}{\partial x^{2}}+\frac{J^{2} R(T)}{c \rho}
$$

ここで, $T(x, t)$ : ワイヤ笑き出し部位置 $x$ での 温度 $(\mathrm{K}), v_{w}$ ：ワイヤ送給速度 $(\mathrm{m} / \mathrm{s}), k:$ ワイヤ材 の熱払散率 $\left(\mathrm{m}^{2} / \mathrm{s}\right)\lceil k=K / c \rho, K$ : 熱伝導率 $(\mathrm{W} /$ $\mathrm{mK})], \rho:$ 密度 $\left(\mathrm{kg} / \mathrm{m}^{3}\right), c:$ 比熱 $(\mathrm{J} / \mathrm{kgK}), J: ワ$ イヤ突き出し部の電流密度 $\left(\mathrm{A} / \mathrm{m}^{2}\right), R(T)$ : 温度 $T$ における抵抗率 $(\Omega \mathrm{m})$ である。

ワイヤ中の電流密度は, 溶接電流 $I(\mathrm{~A})$ とワイヤ 断面積 $S\left(\mathrm{~m}^{2}\right)$ から， $J=I / S$ て与えられる.ワイヤ 径 $d(\mathrm{~m})$ のソリッドワイヤの場合, $J=I /\left(\pi d^{2} / 4\right)$ となるが、コアードワイヤにおいても，金属部とフ ラックス部との間での熱の移動が無視できる場合, 金属部断面積を用いて (1) 式を適用することができ る.

\section{2 突き出し長の時間的变化}

もとより, 突き出し長が変動したり, 電流が增隇 すると電極ワイヤの温度分布は時間的に変化するこ とになる，とくに突き出し長の変動の大きさは，溶
極式アークの安定度を示す指標のひとつである。そ の変動原因としては, 有限の大きさの溶滴が離脱す ることによるものと，ワイヤの送給と溶融のアンバ ランスによるものがある，ここでは，モデルの仮定 から後者の場合を示すと，次式にようになる。

$$
\frac{d E_{x}}{d t}=v_{W}-v_{M}
$$

ただし， $v_{M}$ : ワイヤ溶融速度 $(\mathrm{m} / \mathrm{s})$. ワイヤ端部が 溶融すると同時に離脱するので， $v_{M}$ がワイヤ送給 速度 $v_{W}$ よりも大きい場合，突き出し長はどんどん 短くなっていく．言い換えると $d E_{x} / d t<0$ のとき， 給電チップと母材間の距離が一定の場合，アーク長 が長くなっていく.

ワイヤ端で溶融した金属は実際には，溶滴として 付着しており，次回に述べる電磁力や重力などに よって，ワイヤから離脱することになる，したがっ て，アークからの入熱が大きく，ワイヤ端に付着し ている時間が長い溶滴は，かなり加熱されることに なる。一方，突き出し部への熱流はフーリ工則にし たがい，ワイヤ端 $\left(x=\mathrm{E}_{\mathrm{x}}\right)$ での温度勾配に支配され る. 結局,アークからワイヤに与えられる熱量は, 次式て示されるワイヤ溶融に必要な熱量とワイヤ固 体部への熱伝導に費やされる。

$$
\begin{aligned}
\frac{Q}{S}= & \left.K \frac{\partial T}{\partial x}\right|_{x=E_{\mathrm{x}}} \\
& +\left\{\rho H_{0}-\rho c\left(T_{m}-T_{0}\right)\right\} v_{M}
\end{aligned}
$$

ただし， $Q$ :アークからの入熱 $(\mathrm{W}), H_{0}$ : 溶滴の保 有熱量（溶瀜金属がワイヤから離脱する際に持ち去 る熱量) $(\mathrm{J} / \mathrm{kg}), T_{m}$ ：ワイヤ材の融点 $(\mathrm{K}), T_{0}$ ：給 電チップ $(x=0)$ の温度 $(\mathrm{K})$ である.

\section{3 準定常状態の解}

いま，溶極式アークのアーク長もしくは突き出し 長が一定て時間的に変化せず $\left(d E_{x} / d t=0\right)$, 安定な アークが維持されている場合を考える。つまり，(3) 式によるワイヤの溶融量と送給量がバランスすれ ば,突き出し長が一定になる。このような状態であっ ても, 電流変化に応じて突き出し部の温度は変動す る.

そこで, 溶接電流を一定電流とし, ワイヤの温度 分布が時間的に変化しない準定常状態 $(\partial T / \partial t=0)$ を想定する. ワイヤ材の抵抗率は温度上昇とともに 大きくなるが，(1)式の解析解を得るため， $R(T)=$ $R_{0}$ とおく.このとき，突き出し部の温度分布は次式 で与えられる。 


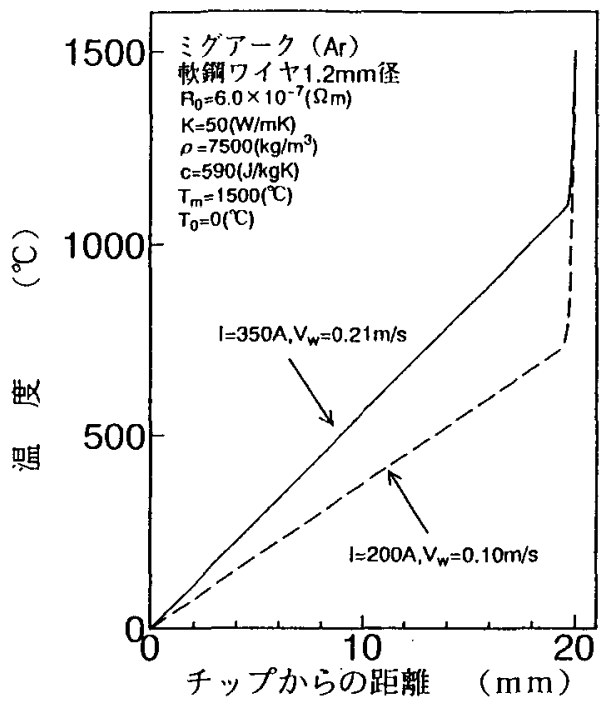

図 2 ワイヤ突き出し部の温度分布

$$
\begin{aligned}
T(x)= & \left(T_{m}-T_{0}-\frac{E_{x}}{v_{W}} \frac{J^{2} R_{0}}{c \rho}\right) \times \\
& \frac{\operatorname{xp}\left(v_{W} x / k\right)-1}{\exp \left(v_{W} E_{x} / k\right)-1}+\frac{J^{2} R_{0}}{c \rho} \frac{x}{v_{W}}+T_{0}
\end{aligned}
$$

図 2 は軟鋼ワイヤ $1.2 \mathrm{~mm}$ 径について, 突き出し長 $\mathrm{E}_{\mathrm{x}}=20 \mathrm{~mm}$ としたときの計算例を示す.なお，この ときのワイヤ送給速度は実験的に求めたものを用い ている。電流 $200 \mathrm{~A}$ と $350 \mathrm{~A}$ のいずれの場合も，給 電チップからの距離に比例して温度が高くなり,ワ イヤ端から $1 \mathrm{~mm}$ 程度の領域てアークからの熱によ り急激に温度が上昇している。ワイヤ径を細径にし て高速で送給する溶接法では，突き出し部の温度に 対して抵抗発熱の影響が大きい。

\section{3. ワイヤ溶融速度}

\section{1 アークによるワイヤの加熱}

（3）においてワイヤ溶融量を左右するアークから の入熱量を考える. 電極ワイヤはアーク放電の陰極 または陽極であり，それそれの電極への入熱は，主 としてアーク電流を運ぶ電子・イオンによって与え られる. 加えて, 高温のアークプラスマからの放射 や熱伝導も奇与する.電極領域の現象は複雑であり, アーク物理としても末だ不明な点が多いため，考え 方の基本を述べることにする゙2.

ミグ・マグ溶接などでは，ワイヤを陽極とする直 流棒プラス (DCEP) を用いることが多いが，一般に 溶極式アーク溶接では, 用途に応じて, 直流棒マイ ナス（DCEN）や交流も使われる.
陽極領域部では，ほほ $100 \%$ 䉓子流となり，アー ク柱からの電子は陽極降下電压 $V_{A}(\mathrm{~V})$ で加速さ れ，陽極に飛び込む。そして、アーク空間よりもポ テンシャルの低い陽極金属内の電子となるので, 陽 極物質の仕事関数 $V_{W A}(\mathrm{~V})$ に相当したエネルギー を与える。すむおち，陽極への入熱 $Q_{A}(W)$ は次式 で表せる。

$$
Q_{A}=I\left(V_{A}+V_{W A}+V_{T}\right)
$$

$V_{T}\left(=(5 / 2) k_{B} T_{e} / e\right):$ アークプラスマ文の電子 のエンタルピーの等価電圧 $(\mathrm{V})$. なお, $T_{e}$ : 電子温 度 $(\mathrm{K}), k_{B}$ : ボルツマン定数 $\left(1.38 \times 10^{-23} \mathrm{~J} / \mathrm{K}\right), e$ : 電子電荷 $\left(1.6 \times 10^{-19} \mathrm{C}\right)$ でる。

陰極部ではアークプラズマからやってきたイオン が，陰極降下電圧 $V_{c}(\mathrm{~V})$ で加速されて陰極表面に 衝突し, 同時に陰極の電子と再結合して電離エネル ギー $V_{I}(\mathrm{~V})$ を与える.一方, 陰極からの電子は陰極 物質の仕事関数 $V_{W C}(\mathrm{~V})$ に相当したエネルギーを もって，アーク空間に放出されるのて，その分だけ 陰極は冷却されることになる.陰極への入熱 $Q_{c}(\mathrm{~W})$ は次式で与えられる.

$$
\begin{aligned}
Q_{c}= & (1-s) I\left\{V_{C}+\left(V_{I}-V_{w C}\right)+V_{T}\right\}- \\
& s I V_{w C}
\end{aligned}
$$

ここで, $s$ : 電子電流率(陰極領域を流れる電流のう ち電子が運ぶ場合で，電子放出機構に依存する）, $V_{T}\left(=(3 / 2) k_{B} T_{I} / e\right):$ アークプラスマ中のイオン の運動エネルギーの等価電压 $(V), T$ ， :イオン温度 (K)である.

$V_{W A}$ と $V_{W C}$ は電極材料によって異なり，3〜4.5 $\mathrm{V} ， V$ ，はプラスマアガスによるが，アルゴンで $15 \mathrm{~V}$ 程度である。また， $V_{C}$ は $10 \mathrm{~V}$ 程度， $V_{A}$ と $V_{T}$ は $1 \mathrm{~V}$ 程度と考光られている。（5) (6) 式から，アーク から電極ワイヤへの入熱は溶接電流に比例すると考 え，次式で表す。

$$
Q=I \phi
$$

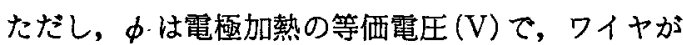
陽極の場合, $\phi=V_{A}+V_{W A}+V_{T}$ となる。

\section{2 ワイヤ溶融速度と溶滴の保有熱量}

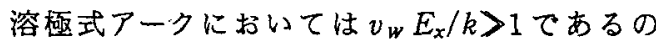
で, 式 (3) (4) (7) から, ワイヤ溶融速度は次式で与 えられる。

$$
v_{M}=\frac{1}{\rho H_{0}}\left(\phi J+R_{0} E_{x} J^{2}\right)
$$

すなわち、ワイヤ溶融速度は電流值によって変える ことができるわけであるが，アークからの入熱量お 


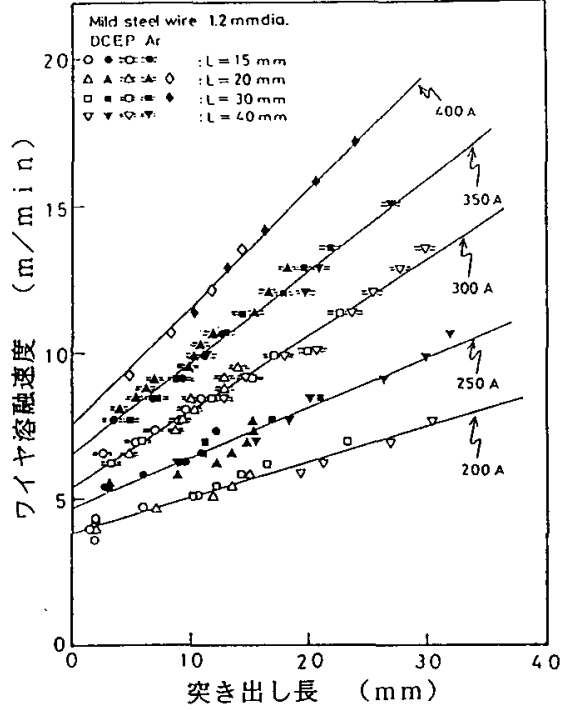

(a) 軟鋼ワイヤ

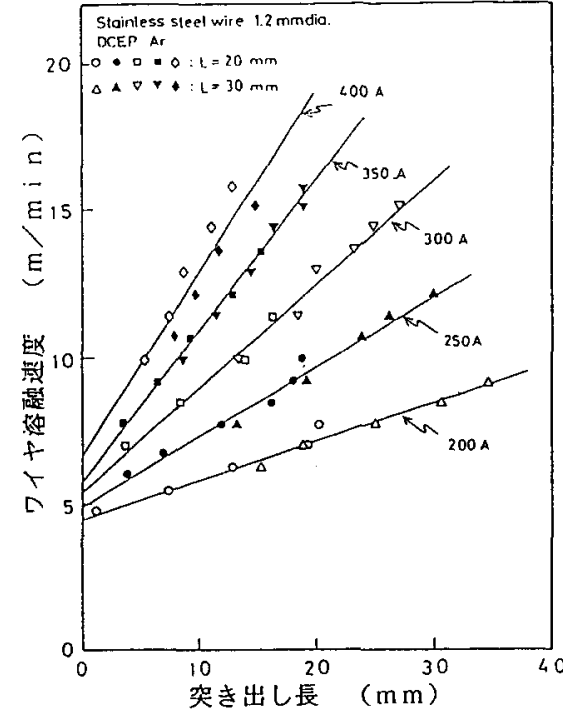

(b) ステンレス鋼ワイヤ

図 3 ワイヤ溶融速度と染き出し長の関係

表 1 ワイヤ溶融速度式の比例定数

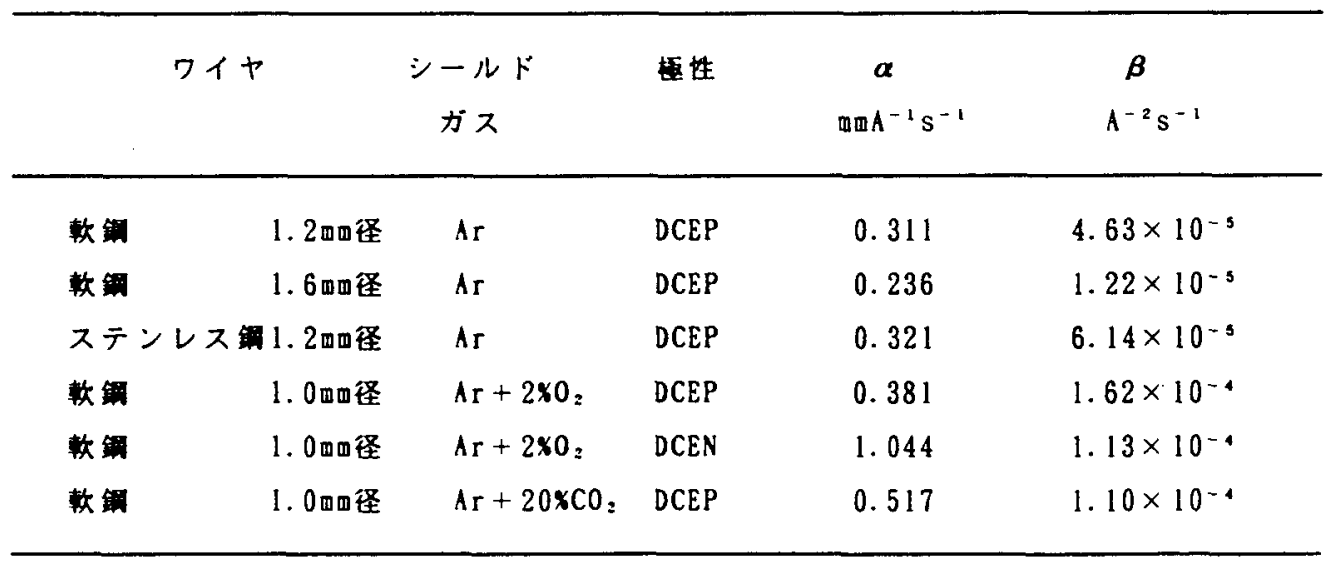

衰 2 ワイヤ溶融速度から求めた溶滴の保有熱量〔( ）内に奏測值を示す〕とアークによる溶融の等価電 圷 (ミグアーク, DCEP, アルコン)

$ワ イ ヤ$
容滴の保有熱量 $H_{0}$

$\mathrm{J} / \mathrm{kg}$
等価電圧 $\phi$

$\checkmark$

\begin{tabular}{|c|c|c|c|c|}
\hline 軟钢 & 1.20®径 & $1.83 \times 10^{6}$ & $\left(1.87 \times 10^{6}\right)$ & 5.7 \\
\hline 軟铜 & 1.6略徍 & $1.62 \times 10^{8}$ & $\left(1.68 \times 10^{6}\right)$ & 6.3 \\
\hline ステンレス铜 & 1.2mm经 & $1.71 \times 10^{6}$ & $\left(1.69 \times 10^{6}\right)$ & 5.3 \\
\hline 銅合金 $(7 / 3 \mathrm{Cu}-\mathrm{Ni})$ & 1.20日径 & $1.29 \times 10^{8}$ & $\left(1.32 \times 10^{6}\right)$ & 5.1 \\
\hline
\end{tabular}


よび突き出し部の抵抗発熱に加えて, 溶滴の保有熱 量に支配される、ワイヤ端部が融点になって, 溶融 すると同時にワイヤから離脱すると, 溶滴の保有熱 量が最小となるので, 効率よくワイヤ溶融が行われ ることになる。

ワイヤ溶融速度あるいは溶融量に関して,これま

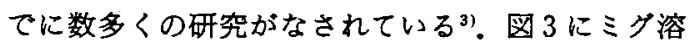
接による実験結果の一例を示す。溶接電流が一定の 場合, ワイヤ溶融速度と突き出し長は直線関係を示 している．その傾きは電流值や材質により異なり， 溶融速度に対する抵抗発熱の寄与は，突き出し衷に もよるが固有抵抗の大きいステンレス鋼や軟鋼では 50\%以上にも達する。これらの実験結果に基づい て,ワイヤ突き出し部の抵抗発熱効果を考慮すると, 次のような実験式が得られる。

$$
v_{M}=\alpha I+\beta E_{x} I^{2}
$$

ただし， $\alpha(\mathrm{m} / \mathrm{As}) と \beta\left(\mathrm{l} / \mathrm{A}^{2} \mathrm{~s}\right)$ は比例定数で，ワ イヤの材質や径, シールドガスなどによって変化す る. 表 1 にダ・マク溶接における $\alpha$ と $\beta$ を示す. 溶融速度に対して，とくにワイヤ径の影響が大きい が，極性を棒マイナスとするとアークから電極への 入熱が増加する.（9)式の物理的な意味としては(8) 式の関係により，ワイヤ材の仕事関数や溶滴の保有 熱量, 抵抗率などと結びついている4,5).したがって, 両者を比較すると，溶滴の保有熱量とアークによる ワイヤ溶融の等価電王を求めることができる（表 2). 溶滴の保有熱量は実測値（200～350 A の平均
(値) $)^{6)}$ とほ近い值を示しており，定性的な議諭に対 しては上述のモデルを適用してもよいと考えられ る.

$$
\text { 4. おわりに }
$$

電極ワイヤの溶融現象は, 本質的には溶谪の離 脱・移行をともなう非定常な現象であり，取扱いも 複雑になる，また，アークからの入熱が固体ワイヤ およびワイヤ端の溶融金属表面のどのような領域に 与えられるかも重要である，電極表面への電流の流 入出点であり, 入熱点にもなる陰極領域と陽極領域 の現象やワイヤ端の溶滴内での熱輸送機構など明ら かではなく、今後の実験的および理論的検討による 解明が待たれる。

\section{参 考 文 献}

1）黄地：溶接アークプロセスの物理〔I〕，溶接学会 誌, vol. 63, No. 4, 1994.

2) ランカスター編著: 溶接アークの物理, 黒木出版, 1990.

3) 例兄ば, Lesnewich, A: Weld. J., 37, 1968.

4) Halmoy, E: Wire melting rate, droplet temperature, and effective anode melting potential, Conference on Arc Physics and Weld Pool Behavior, 29, 1979.

5）丸尾, 平田, 野田：パルス MIG 溶接に抢けるワイ ヤの溶融速度, 溶接学会論文集, Vol. 3, No. 1, 1985.

6) 丸尾, 平田, 野田：パルス MIG 溶接における溶滴 の保有熱量と温度, 溶接学会論文集, Vol. 2, No. 4, 1984 .

名著最新版を完訳!!
溶
接
P
$>0$
物 理
定洒 10,000 円（税込）
A 5 判 370 面
第二版 J.F.ランカスター編著
ISBN4-906110-25-8

溶接学会溶接アーク物理研究委員会 100 回記念刑行 